\title{
KONSTRUKSI IDEOLOGI GENDER PADA MAJALAH WANITA (ANALISIS WACANA KRITIS MAJALAH UMMI)
}

\author{
Ummy Hanifah \\ Dosen Fakultas Ilmu Komunikasi Universitas Tama Jagakarasa Jakarta
}

\begin{abstract}
UMMI's magazine is one of Islamic magazine which is segmented for women and has positioned their self as da'wa media. The problems of this research are how UMMI construct the gender rules to their readers and how that rules are presented in this media. The approach that used in this research is the theory of content of media from Shoemaker and Reese. There are many factors that influence of content of media such as individual factors, media's rutinity, organizational factor, extra media and ideologi. Method being used in this research was qualitative-descriptive along with critical discourse analysis from Norman Fairclough. The result showed that UMMI successfully construct double rules to their readers.
\end{abstract}

Key Words: content of media, critical discourse analysis, framing analysis

\begin{abstract}
Abstrak
Focus penelitian ini ialah artikel-artikel yang berupa feature yang menggambarkan peran perempuan di sektor publik pada majalah UMMI selama tahun 1990 sampai dengan tahun 2004. Pemilihan majalah UMMI dilakukan karena UMMI merupakan salah satu majalah islam yang dikhususkan bagi kaum wanita dan memposisikan dirinya sebagai media dakwah. Selain itu, UMMI sarat sekali dengan nilai-nilai keislaman serta membawa visi dan misi yang sesuai dengan ajaran islam. Penelitian ini ingin menjawab bagaimanakah UMMI mengkonstruksikan peran gender kepada pembacanya dan bagaimanakah peran tersebut ditampilkan. Pendekatan yang digunakan dalam penelitian berasal dari teori isi media yang menyatakan bahwa banyak faktor yang mempengaruhi terhadap isi media yaitu faktor individual (wartawan), faktor rutinitas media, organisasi, extra media dan faktor ideologi. Metode yang digunakan dalam penelitian ini ialah analisis wacana kritis dengan pendekatan kualitatif dan konstruktivisme. Teori yang digunakan ialah teori isi media, konstruksi gender, praktek wacana media yang meliputi analisis wacana dari Norman Fairclough, analisis framing. Hasil penelitian menemukan bahwa UMMI mengkonstruksikan peran ganda kepada pembacanya melalui analisis teks yang dilakukan serta ideologi media tersebut.
\end{abstract}

Kata Kunci: isi media, analisis wacana kritis, analisis framing

\section{Pendahuluan}

Pada saat sekarang ini, banyak sekali kaum perempuan yang terjun ke sektor publik yang selama ini diperuntukkan hanya bagi kaum laki-laki saja. Bahkan banyak sekali perempuan yang menduduki jabatan strategis yang pada waktu dahulu jabatan tersebut merupakan sesuatu yang tabu bagi kaum perempuan. Selama kurun waktu 1980 - 1990, tingkat partisipasi kaum perempuan meningkat sebanyak 55\% sementara tingkat partisipasi kerja laki-laki meningkat sebanyak 35.5\% (Sensus Penduduk 1980 dan 1990). Peningkatan ini disebabkan tuntutan ekonomi, peningkatan pendidikan perempuan dan semakin terbukanya peluang bagi perempuan untuk memasuki sektor publik. ${ }^{1}$ 
Meningkatnya jumlah kaum wanita yang melakukan aktivitas di luar rumah menunjukkan kaum perempuan menginginkan adanya kesetaraan gender antara pria dan wanita. Ratna Megawangi mengartikan kesetaraan gender dengan mengkaitkannya dengan istilah diskriminasi terhadap perempuan, subordinasi, penindasan, perlakuan tidak adil dan sebagainya. ${ }^{2}$ Upaya untuk meningkatkan kesetaraan gender sesuai dengan konvensi penghapusan segala bentuk diskriminasi terhadap wanita Perserikatan Bangsa-bangsa (PBB) yang telah mengalami ratifikasi dan disahkan menjadi UU No.7 tahun 1984.

Sejak bertahun-tahun lamanya, kaum perempuan selalu diidentifikasikan dengan bidang kegiatan privat, di dalam rumah dan keluarga sedangkan laki-laki di bidang kegiatan publik, kehidupan politik dan ekonomi. Tradisi pengidentifikasian ini telah menimbulkan berbagai macam tindakan diskriminatif terhadap kaum perempuan. Ini disebabkan adanya ideologi yang paling kuat dalam menyokong perbedaan gender dengan membagi dunia menjadi wilayah publik dan privat. Pembedaan peran sosial antara laki-laki dan wanita berawal dari perbedaan biologis antara laki-laki dan perempuan. Perbedaan ini melahirkan perbedaan peran laki-laki dan perempuan dalam masyarakat.

Media massa turut mensosialisasikan dan melanggengkan ideologi yang timpang dan diskriminatif terhadap perempuan. Hal ini terlihat dari pemilihan angel dalam suatu berita atau diksi (permainan kata) yang digunakan dalam penulisan berita khususnya yang menyangkut ketidakadilan terhadap perempuan. Mengutip pendapat Hardjana, ${ }^{3}$ wanita umumnya ditampilkan sebagai alat jual dan objek jual. Sebagai “objek jual”, wanita tampil sebagai objek seksual, materi pornografi dan korban kriminal. Media massa tidak hanya berfungsi mempengaruhi masyarakat tetapi media juga ditentukan oleh kondisi masyarakat lingkungannya. Shoemaker dan Reese menyebutkan bahwa media dipengaruhi oleh dua hal yaitu pengaruh yang berasal dari dalam media sendiri dan pengaruh yang berasal dari luar (eksternal). Pengaruh internal media massa berasal dari pekerja media, rutinitas media, organisasi media serta ideologi (Shoemaker dan Reese, 1996).

Sesuai dengan kedudukannya yang subordinat, penggambaran perempuan dalam media massa tidak jauh dari dunia domestik, dunia yang dianggap dekat dengan "kodrat" perempuan. Tamrin Amal Tomagola ${ }^{4}$ dalam penelitiannya tentang iklan dan artikel di majalah Femina, Kartini, Sarinah dan Pertiwi selama tahun 1986-1990 menemukan lima citra perempuan yang digambarkan oleh iklan di media massa. Pertama, citra pigura yaitu perempuan dituntut untuk tampil memikat. Kedua ialah citra pilar, dimana perempuan harus dapat mengelola dunia domestiknya dengan baik. Ketiga, ialah citra pinggan bahwa perempuan tidak perlu merasa tersiksa dengan pekerjaannya di dapur bahwa pekerjaan dapur juga bias menjadi hal yang menyenangkan. Keempat ialah citra peraduan, yang menempatkan pandangan dan anggapan bahwa sudah "sewajarnya" perempuan diperlakukan sebagai objek segala jenis pemuasan laki-laki. Kelima ialah citra pergaulan yang tidak lepas dari fisik perempuan yang harus tampil menarik agar tidak memalukan jika harus berhubungan sosial dengan individu lainnya.

Sementara itu, Arbi (1998) mengenai stereotype perempuan di media cetak wanita pada majalah femina tahun 1970-an dan 1990-an menemukan perbedaan yang menonjol antara penampilan peran pria dan wanita dan hubungan komunikasi antara keduanya. Menurut Arbi, Femina tahun 1970-an lebih cenderung menampilkan peran tradisional, menyusul pra transisi dan peran ganda wanita. Sebaliknya, Femina tahun 1990-an cenderung menampilkan peran egalitarian, peran kontemporer, peran ganda pria dan wanita dan terakhir ialah multi peran bagi pria dan wanita.

Majalah UMMI merupakan salah satu majalah yang diperuntukkan bagi kalangan perempuan dan mengusung nilai-nilai dakwah dalam setiap pemberitaannya. Oleh karena 
itu, dalan penelitian ini mengangkat majalah UMMI sebagai objek penelitian. Berkaitan dengan hal tersebut, permasalahan yang diangkat dalam penelitian ini ialah bagaimana UMMI mengkonstruksikan peran gender kepada pembacanya? Dan bagaimanakah peran wanita yang ditampilkan dalam majalah tersebut?

\section{Teori Isi Media}

Shoemaker dan Reese mengartikan isi dengan keseluruhan informasi verbal dan visual yang lengkap yang didistribusikan oleh media massa. ${ }^{5}$ Informasi kuantitatif mencakup atribusi-atribusi isi media yang dapat diukur atau dihitung. Sedangkan informasi kualitatif mencakup ukuran yang dapat memberikan informasi yang penting tentang jumlah jangkauan dan pandangan yang menjadi prioritas. Shoemaker dan Reese menyebutkan bahwa pengaruh terhadap media massa berasal dari pekerja media, rutinitas media, organisasi media serta ideologi. Secara lebih jelas, pengaruh terhadap isi media ada dua yaitu pengaruh yang berasal dari dalam media dan pengaruh yang berasal dari luar media.

1. Pengaruh Internal

a. Pengaruh dari Individu Pekerja Media

Karakteristik komunikator seperti gender, etnis dan latar belakang serta pengalaman individu tidak hanya membentuk sikap, nilai-nilai, keyakinan personal komunikator tetapi juga mengarahkan latar belakang dan pengalaman profesional komunikator. Pengalaman ini kemudian membentuk peranan-peranan profesional komunikator dan etika. Peranan dan etika profesional ini berdampak langsung pada isi media massa, sementara efek sikap, nilai dan keyakinan personal pada isi media massa bersifat tidak langsung.

b. Pengaruh Rutinitas Media

Studi mengenai rutinitas media dikaitkan dengan perspektif organisasional pada media massa. Paul Hirsch mengatakan bahwa media massa mungkin menyajikan fungsi-fungsi yang berbeda tetapi mereka memiliki banyak kesamaan organisasional. Praktek rutinitas media membentuk lingkungan yang dekat dengan para pekerja media seperti reporter, editor dan penulis. Rutinitas memiliki arti yang penting karena mereka mempengaruhi realitas sosial yang digambarkan oleh media. Bahkan Tuchman menyarankan bahwa dengan mengijinkan peristiwa yang terjadi setiap hari telah menjadikan berita menjadi disadari dan dibentuk kembali.

c. Pengaruh Organisasi

Organisasi diartikan sebagai satuan sosial ekonomik yang formal yang memperkerjakan pekerja media untuk menghasilkan isi media. ${ }^{6}$ Gans dan Sigal memandang faktor ekonomi memiliki pengaruh tidak langsung pada keputusan redaksional. Untuk merespon hal ini, maka organisasi dapat melakukan dua hal yaitu menjual keuntungan mereka lebih banyak kepada orang yang tepat dan mengurangi biaya produksi. Selain itu, kepemilikan (ownership) suatu organisasi media massa juga ikut menentukan isi media massa. Hal ini terlihat ketika pemilik berusaha menentukan atau memaksakan pandangannya terhadap isi media.

2. Pengaruh yang Berasal dari Luar Organisasi Media

Pengaruh yang berasal dari luar organisasi media meliputi sumber informasi yang menjadi isi media seperti kelompok kepentingan, kampanye, sumber pendapatan seperti iklan dan audiens, institusi sosial lainnya seperti bisnis dan pemerintah, dan lingkungan ekonomi dan teknologi.

a. Pengaruh Ideologi 
Littlejohn mengatakan bahwa ideologi bersifat menembus dan bersifat tidak sadar. Ideologi yang dominan mengabadikan kepentingan kelas tertentu daripada yang lain dan media memainkan peranan dalam proses ini. ${ }^{7}$ Bahkan Altschult berpendapat bahwa media merefleksikan ideologi sebagai pihak yang membiayai mereka. ${ }^{8}$

b. Konstruksi Sosial tentang gender

Fakih membedakan antara gender dengan seks. Seks merujuk kepada pembagian dua jenis kelamin manusia yang ditentukan secara biologis yang melekat pada jenis kelamin tertentu. Sedangkan gender ialah suatu sifat yang melekat pada kaum laki-laki dan perempuan yang dikonstruksi secara sosial maupun kultural. ${ }^{9}$ Gender berubah dari waktu ke waktu, dari tempat ke tempat lain bahkan dari kelas ke kelas lain. Sementara jenis kelamin biologis (seks) tetap tidak berubah. ${ }^{10}$ Terbentuknya perbedaan gender ditentukan banyak hal di antaranya dibentuk, disosialisasikan, diperkuat atau bahkan dikonstruksi secara sosial dan budaya melalui ajaran keagamaan maupun negara. Perbedaan gender selanjutnyaa akan melahirkan peran gender yang pada akhrinya akan menimbulkan ketidakadilan gender. Bentuk manifestasi ketidakadilan gender dalam hal mempersepsi, memberi nilai serta dalam pembagian tugas antara laki-laki dan perempuan.

\section{Praktek Wacana Media}

Dalam analisis wacana, terdapat tiga pandangan mengenai bahasa. Pandangan pertama diwakili oleh kaum positivism-empiris. Menurut aliran ini, bahasa merupakan jembatan antara manusia dengan objek di luar dirinya. Salah satu cirri dari pandangan ini ialah adanya pemisahan antara pemikiran dan realitas. Analisis wacana dimaksudkan untuk menggambarkan tata aturan kalimat, bahasa dan pengertian bersama. Pandangan kedua ialah konstruktivisme. Dalam aliran ini, bahasa tidak lagi hanya dilihat sebagai alat untuk memahami realitas objektif belaka dan yang dipisahkan dari subjek sebagai penyampai pernyataan. Konstruktivisme menganggap subjek sebagai faktor sentral dalam kegiatan wacana serta hubungan-hubungan sosialnya. Pandangan ketiga ialah kritis. Dalam aliran ini, analisis wacana menekankan pada konstelasi kekuatan yang terjadi pada proses produksi dan reproduksi makna. Bahasa dipahami sebagai representasi yang berperan dalam membentuk subjek tertentu, tema wacana tertentu, maupun strategi-strategi di dalamnya. Oleh karena itu, analisis wacana dipakai untuk membongkar kuasa yang ada dalam setiap proses bahasa, batasan-batasan apa yang diperkenakan menjadi wacana, perspektif apa yang harus dipakai dan topik yang dibicarakan. ${ }^{11}$

Beberapa model analisis wacana yang populer adalah analisis wacana kritis yang dikembangkan Norman Fairclough dan analisis framing. Menurut Fairclough, Analisis wacana kritis berisi metode-metode yang menekankan multilevel analysis yang mempertautkan analisis pada jenjang meso atau makro. Fairclough memusatkan bahasa sebagai praktek kekuasaan. Bahasa secara sosial dan historis ialah bentuk tindakan, dalam hubungan dialektik dengan struktur sosial. Oleh karena itu, analisis harus dipusatkan pada bagaimana bahasa itu terbentuk dan dibentuk dari relasi sosial dan konteks sosial tertentu. ${ }^{12}$

Analisis wacana yang berasal dari Fairclough dilakukan melalui dua perspektif yaitu: perspektif communicative events dan the order of discourse. Communicative events menganalisa hubungan antara tiga dimensi yaitu teks, discourse practice dan sociocultural practice. Sedangkan order of discourse lebih melihat kepada keseluruhan struktur dan bagaimana teks dalam konsteks sosial dan perubahan budaya. ${ }^{13}$

Analisis Framing dalam perspektif komunikasi digunakan untuk membedah caracara atau ideologi media saat mengkonstruksi fakta. Dengan kata lain, framing merupakan 
pendekatan untuk mengetahui bagaimana perspektif wartawan ketika menyeleksi suatu isu dan menulisnya. Cara pandang atau perspektif pada akhirnya menentukan fakta apa yang diambil, bagian mana yang ditonjolkan dan hendak dibawa kemana berita tersebut. ${ }^{14}$

Model Gamson dan Modigliani didasarkan atas pendekatan konstruksionis yang melihar representasi media terdiri dari package intertpretative yang mengandung konstruksi makna tertentu. Di dalam package ini terdapat dua struktur yaitu core frame dan condensing symbols. Struktur pertama ialah pusat organisasi elemen-elemen ide yang membantu komunikator untuk menunjukkann substansi isu yang tengah dibicarakan. Sedangkan struktur kedua mengandung dua sub struktur yaitu framing devices dan reasoning devices

\section{Paradigma Penelitian}

Studi ini menggunakan paradigm konstruktivisme. Agus Salim menyatakan bahwa secara ontologis, realitas tidak dapat digeneralisasikan kepada semua orang seperti yang dilakukan kalangan positivis atau post positivis. Aliran ini juga memandang kenyataan sebagai sesuatu yang relatif, tempat kenyataan ada dalam bentuk konstruksi mental manusia. Secara epistemologis, hubungan antara peneliti dengan objek bersifat satu kesatuan, subjektif dan hasil perpaduan interaksi di antara keduanya. Secara metodologis, aliran ini menyatakan bahwa penelitian harus dilakukan di luar laboratorium, yaitu di alam bebas secara wajar untuk menangkap fenomena alam apa adanya dan secara menyeluruh tanpa campur tangan dan manipulasi pengamat atau peneliti. Konstruktivisme menerapkan hermeunetik dan dialektik dalam proses pencapaian kebenaran.

Penelitian ini bersifat deskriptif-kualitatif karena ingin menggambarkan konstruksi peran dalam majalah wanita, menggambarkan proses produksi dan konsumsi media dan menghubungkannya dengan ideologi dan kondisi lingkungan dimana media tersebut berada.

Peneliti menggunakan metode analisis wacana kritis (critical discourse analysis) yang didasarkan atas pemikiran Norman Fairclough. Peneliti memilih analisis Fairclough karena pemikiran yang berasal dari Fairclough mengintegrasikan secara bersama-sama analisis wacana yang didasarkan atas linguistik dan pemikiran sosial politik dan juga diintegrasikan dengan perubahan sosial. Analisis wacana kritis ini akan dilakukan melalui perspektif analisis communicative events yaitu analisis berdasarkan hubungan antara tiga dimensi yaitu teks, discourse practice dan praktek sosiokultural

Objek penelitian ini ialah majalah UMMI. Majalah UMMI dipilih karena majalah ini merupakan salah satu majalah wanita yang memiliki tujuan dakwah dan telah memposisikan dirinya menjadi media dakwah. Penelitian dilakukan terhadap UMMI terbitan tahun 1990-an sampai 2004. Majalah UMMI yang menjadi objek penelitian berjumlah 5 edisi yaitu edisi 7/X/98, edisi 11/X/99, edisi 8/XII/2000, edisi 6/XIII/2001, edisi 6/XIV/2002. Dari masing-masing edisi tersebut diambil satu artikel yang berhubungan dengan tema yang peneliti angkat.

Untuk jenjang teks, unit analisisnya ialah artikel yang terdapat pada majalah UMMI yaitu bahasan utama, sedangkan untuk jenjang discourse practicenya unit analisisnya ialah institusi majalah UMMI dan level praktik sosio-kulturalnya ialah menghubungkannya dengan konsteks sosial.

Analisis dilakukan dengan dua cara, yaitu analisis teks dan praktik wacana (discourse practice). Analisis teks akan dilakukan dengan analisis framing. Teknik analisis yang akan digunakan berasal dari Gamson dan Modigliani. Menurut mereka, wacana media 
merupakan satu gugusan perspektif interpretasi (interpretative package) saat mengkonstruksi dan memberi makna suatu isu. ${ }^{15}$

Dalam studi ini, frame atau bingkai yang menjadi gagasan sentral tersebut ialah:

1. Peran ganda

2. Dikotomi peran dalam keluarga

3. Menjaga niat dalam bekerja

4. Kemandirian

5. Kesetaraan

Setelah mendapatkan frame, peneliti melanjutkan pada analisis dengan melihat struktur framing yang berasal dari Gamson dan Modigliani yang terdiri atas perangkat retoris dan linguistik yang disebut dengan condensing symbols dan terdiri atas framing devices dan reasoning devices.

Praktik wacana (discourse practice) terdiri atas produksi teks, konsumsi teks, dan praktis sosio-kultural. Analisis produksi teks dilihat dari karakteristik media yang diteliti (majalah UMMI) berdasarkan latar belakang sejarah berdirinya, pengamatan tentang isi media (jumlah halaman, hal-hal umum yang ditampilkan dan jumlah rubrik berikut desktripsi setiap rubrik), gaya penyajiannya dan sebagainya. Analisa ini akan dilakukan dengan wawancara mendalam dengan pihak yang dianggap memiliki kapasitas untuk memberikan informasi yang akurat.

Konsumsi teks hanya dilakukan pada data sekunder mengenai segmentasi pasar, karakteristik khalayak dan sebagainya. Analisis sociocultural practice didasarkan atas asumsi bahwa konteks sosial yang ada di luar media mempengaruhi bagaimanakan wacana yang muncul di media. Untuk level sociocultural practice dilakukan dengan melihat hubungan artikel dan frame yang muncul dengan berbagai faktor yang mempengaruhi isi media.

\section{Analisis dan Temuan Penelitian}

\section{Analisis Teks}

Teras feature yang sering kali digunakan dalam tulisan feature yang diteliti ialah narasi pribadi. Dalam feature jenis ini, keterlibatan penulis ditonjolkan. Gaya tulisan ini memperlihatkan kekuatan mengenai berbagai peristiwa, fenomena atau masalah dari sudut pandang pribadi reporter.

Untuk menunjukkan intentisitas hubungan atau relasi antara reporter dengan berbagai peristiwa, fenomena atau masalah, maka penggunaan kata ganti orang pertama, tunggal atau jamak rnenjadi hal penting untuk diperhatikan. Contoh tulisan dengan feature narasi pribadi, misalnya :

"Saya sadar, di dunia kerja seperti juga di tempat lain, memang belum sepenuhnya

diwarnai dengan nilai-nilai Islam. Bagi saya, itu adalah tantangan. Saya harus

berupaya semaksimal mungkin untuk mengubahnya" ("Bekerja on Mission",

Ummi edisill/X/99).

Analisis teks majalah UMMI akan dilakukan dengan analisis framing yang merujuk pada konsep Gamson dan Modigliani. Berdasarkan pengamatan peneliti terhadap edisi UMMI ditemukan 5 frame atau bingkai yang merupakan gagasan sentral.

Teks 1

Judul : Dunia Mau Kiamat

Sumber : : UMMI edisi 7/X/98

Frame : Peran Ganda

Framing Devices

Metaphora:

- Istri banting tulang, suami ongkang-ongkang 
- Suami sudah berusaha mencari kerja ke sana kemari, istilahnya sampai tetes darah penghabisan belum dapat juga, baru istri dapat membantu suaminya

- Seharusnya istri menolak diperlakukan seperti sapi perahan

Catchphrases:

- Jangan membudaya

Exemplars:

- Istri sahabat Ibnu Mas'ainab yang membantu suaminya mencari nafkah, tapi tetap menjalankan tugas pokoknya sebagai ibu dari anaknya dan istri dari suaminya

- Sepanjang istri tetap menjalankan fungsinya mendidik anak dan merawat rumah tangga maka sah-sah saja ia membantu suami menghidupi keluarga

- Dalam kondisi tidak normal, boleh saja terjadi istri bekerja mencari nafkah sementara suami mengurus rumah tangga

Depictions:

- Tidak islami

- Kondisi aneh

Visual Images:

- Gambar suami istri yang bertukar peran dimana sang istri berperan di sektor publik sedangkan suami yang melakukan peran di dalam rumah tangga

Reasoning Devices:

- Dalam Islam, pembagian kerja antara laki-laki dan perempuan sebenarnya tidak ada batasan jelas, semua bekerja sesuai dengan kodrat yang telah Allah berikan.

Appeals to Principle:

- Jika itu (istri bekerja) bersifat darurat dan sementrara, semisal suami sebagai penopang ekonomi keluarga di PHK sehingga tidak punya pekerjaan maka si istri yang lebih memiliki potensi boleh membantu suami.

Consequences:

- Istri diperbolehkan bekerja untuk membantu suami sepanjang bukan sebagai tugas utama

Teks 2

Judul : Fitnah Dunia Kerja

Sumber : UMMI edisi 11/X/99

Frame : Menjaga Niat dalam Bekerja

Framing Devices

Metaphors:

- Sekali kita terjebak pada nimatnya menghitung uang, kita seperti meneguk air laut

- Kita menjadi maniak kerja demi uang

- Bukan mustahil bila ia pun akan terlibat dalam berbagai permainan kotor

- Saling sikut, saling makan dan menjatuhkan

Catchphrases: -

Exemplars:

- Sebagian besar perempuan berangkat ke dunia kerja dengan menyertakan alas an ekonomi sebagai motivasinya.

- Karir oriented dan perubahan idealisme muslimah bekerja adalah sebagian dari bentuk adaptasinya terhadap dunia kerja yang kompetitif.

- Ketika berada di bawah orang akan berusaha sekuat tenaga naik ke atas dan bila telah di atas perlu mempertahankan diri agar tidak melorot ke bawah. 
- Bagi perempuan, memiliki uang sendiri dapat berdampak pada berkurangnya atau hilangnya ketergantungan materi pada orang lain.

Depictions:

- Pragmatis

- Materialistis

Visual Images:

- Gambar terdapatnya interaksi antara laki-laki dan perempuan dalam memasuki gerbang dunia kerja

Reasoning Devices:

Roots:

- Motivasi bekerja biasanya ialah untuk beramal saleh di masyarakat dengan melalui aplikasi ilmu.

Appeals to principle:

- Alasan utama saya bekerja ialah ibadah pada-Nya dengan memanfaatkan potensi yang saya punya.

Consequences:

- Memperoleh pengakuan orang atas prestasi kerja yang berdampak pada penerimaan nilai-nilai Islam di lingkungan kerja.

Teks 3

Judul : Istri Masalah ?

Sumber : UMMI edisi 8/XII/2000

Frame $\quad$ : dikotomi peran dalam keluarga

Framing Devices

Metaphors:

- ... ternyata tidak cocok karena merasa unsure non fisiknya tidak nyambung

- Istri bablas, suami ongkang-ongkang

- Jangan dimanjakan hingga tidak otonom dan menggondel pada orang tuanya

Catchphrases: --

Exemplars:

- Kalau istri gajinya lebih, apakah ada aturannya dia jadi lebih berkuasa?

- Dan seharusnya istri membantu suami menjadi imam yang baik dengan menjadi makmum yang baik

- ... karena sebenarnya sang istri tidak menempatkan diri sebagai makmum yang baik

- Ia tidak memerankan fungsinya sebagai penanggungjawab keluarga

- Mereka saling mendukung untuk mencapai kesuksesaan tanpa lepas dari kerangka imam-makmum.

Depictions:

- Sekufu' (setara)

- Visual images:

- Foto sepasang suami istri dimana istri digambarkan patuh kepada suami dengan mencium tangan suaminya.

Reasoning Devices

Roots:

- Soal kelebihan gaji atau harta yang dimiliki seorang istri tidak bias dicampuradukkan dengan soal kepemimpinan dalam rumah tangga

Appeals to Principle: 
- Banyak rumah tangga yang menjalani kekacauan dan tidak harmonis karena ketidakmampuan pasangan menjalani peran imam-makmum dengan benar

Consequences:

- Ketika pertukaran peran (imam-makmum) terjadi secara meluas, permanen dan penuh kesadaran, maka inilah salah satu ganda kehancuran tata nilai agama

Teks 4

Judul : Menjadi leader dengan Wirausaha

Sumber $\quad$ : UMMI edisi 6/XIII/2001

Frame : Mandiri

Framing Devices

Metaphors:

- Baru dua tahun bekerja, posisinya sudah meroket menjadi sekretaris eksekutif

- Kalau pakai istilah Prof. Wijoyonitisastro hanya menjadi kulia agung

- Ia mampu bermain cantik dan lentur dalam berwirausaha

Catchphrases:

- Tetap yang akan leading ialah entrepreneur

Exemplars:

- Kita mungkin tidak asing dengan nama-nama seperti Bob Sadino, Abu Rizal Bakri, DEwi Motik...mereka bukanlah pegawai kantoran melainkan wirausahawan

- Seorang entrepreneur harus selalu siap dengan terobosan-terobosan baru, termasuk berupaya meluaskan pergaulannya

Depictions:

- Berani mengambil resiko

- Pekerja keras

- Displin

Visual Images:

- Para pekerja yang sednag menjahit di rumah

- Seorang foto entrepreneur wanita yang sedang mengarahkan pegawainya

Reasoning Devices

Roots:

- Seorang entrepreneur bukan berpikir mencari pekerjaan tetapi berpikir membuka pekerjaan

Appeals to Principles:

- Seorang enterpreneurlah yang bisa mewujudkan kreasi dan inovasinya untuk sesuatu yang bermanfaat

Consequences;

- Berwirausaha sangat cocok untuk wanita karena bisa dimulai dari rumah

Teks 5

Judul : Shaliha di dalam dan di luar rumah

Sumber : UMMI edisi 6/XIV/2002

Frame : Kesetaraan

Framing Devices

Metaphors:

- Masyarakat juga mempunyai stereotype bahwa seorang ibu bekerja ialah sumber bencana sehingga ia dipersalahkan...

- Si anak akan melihat wah ibu saya banting tulang 
Catchphrases:

- Agar setiap manusia itu bias menjadi orang-orang yang produktif dalam kesalehannya Exemplars:

- Para shahabiyah yang berkecimpung dalam beragam peran dan aktivitas, baik peran publik maupun domestik

- Perilaku tersebut hendaknya dijadikan teladan oleh para muslimah sekarang untuk saling membantu dengan sesame sehingga setiap muslimah tetap dapat mengoptimalkan potensinya.

- Di zaman Nabi, saat pemahamn keislaman begitu mendalam, adanya lingkungan yang Islami dan bermunculan para muslimah pelopor menyebabkan multi peran yang dilakukan muslimah tidak masalah

Depictions:

- Produktif

- Pede

- Berkualitas

Visual images:

- Seorang foto yang memilih perannya sebagai ibu

- Para wanita yang melakukan unjuk rasa

Reasoning Devices

Roots:

- Ruang lingkup ajaran Islam untuk beramal saleh itu sangat luas, baik secara pribadi maupun sosial, domestik atau publik dan ditujukan buat siapa saja, laki-laki atau perempuan

Appeals to Principle:

- Saat suami tidak ada di rumah, para shahabiyatkan harus menjalankan peran ibu sekaligus ayah yang antara lain sebagai penyangga ekonomi

Consequences:

- Dalam kaitan dengan pilihan, apakah perempuan akan berkiprah di dalam atau di luar rumah, maka dukungan suami menjadi satu tiang pondasi utama agar pilihannya membawa manfaat

\section{Analisis Praktek Wacana}

a. Analisis Produksi Teks

1) Sejarah Berdirinya Majalah UMMI

UMMI berada di bawah naungan PT. KIMUS BINA TADZKIA. Sejak didirikannya, UMMI sudah memposisikan dirinya sebagai sebuah media dakwah bagi kalangan wanita terlebih lagi UMMI dilahirkan dengan motivasi dakwah. Bagi UMMI, wanita merupakan separuh lebih dari jumlah populasi negeri yang berpengaruh terhadap kondisi masyarakat. Jika mereka baik (shalihat), maka akan lahirlah individu-individu shalih dan shalihah dalam genggamannya.

Sebagai sebuah media wanita yang Islami, UMMI memiliki visi dan misi yang sesuai dengan ajaran Islam. Adapun visi UMMI ialah media wanita islami yang bermutu dan berpengaruh dalam pembentukan karakter wanita, masyarakat dan bangsa dengan tiras dan sebaran yang signifikan dari masa ke masa. Dalam bahasa yang lebih sederhana ialah UMMI berusaha untuk menjadi yang terbaik dalam mendidik kaum wanita. Sedangkan misi UMMI ialah menjadi media akselarator dan dinamisator bagi terbentuknya karakter wanita shalihah, istri yang 
taat dan mulia (zaujah muthi'ah wa karimah) dan ibu pendidik (ummu madrosah). Identitas wanita Islami merupakan motto serta brand image UMMI.

2) Isi Majalah UMMI

Berdasarkan wawancara yang peneliti lakukan, UMMI berisi berbagai macam pengetahuan yang dapat membuat wanita mendapat predikat perempuan shalihat dan cerdas. Pengetahuan tersebut ialah pengetahuan agama, pengetahuan sosial, kesehatan dan pendidikan anak. Sedangkan secara umum, UMMI berisi berbagai macam rubrikasi yang dibutuhkan perempuan untuk berkembang menjadi insan mulia berkepribadian Islami.

Dalam majalah UMMI sendiri, narasumber terdiri dari dua jenis yaitu narasumber tetap (contributor) dan narasumber tidak tetap. Untuk contributor, hubungan yang terjalin terbatas berdasarkan kedekatan. Sedangkan narasumber lepas, hubungan yang terjalin hanya biasa saja tetapi UMMI berusaha menjaga hubungan yang terbina. Dalam memilih narasumber, UMMI melihat kredibilitas moral dan keahlian dalam bidangnya.

3) Iklan Majalah UMMI

Sebagai sebuah media dakwah yang diposisikan khusus untuk wanita, terdapat seleksi ketat terhadap iklan yang masuk. Disebabkan keinginan UMMI untuk tetap menjaga etika dan kaidah syar'i, maka iklan yang masuk ke UMMI harus tampil islami.

4) UMMI dan Konsep Kesetaraan Wanita

Sebagai media dakwah yang memposisikan dirinya untuk kaum wanita, UMMI memandang dikotomi antara publik dan privat (domestik) merupakan peran yang sifatnya tidak baku tetapi hanya sekedar orientasi tujuan dimana laki-laki harus berada di sektor publik sementara wanita berada di sektor domestik. Menurut UMMI, adanya perbedaam publik dan privat dalam memilih peran merupakan pilihan sadar wanita tersebut. UMMI juga mengakui adanya perbedaan antara lakilaki dan perempuan secara biologis maupun psikologis. Tetapi perbedaan tersebut bukanlah perbedaan yang mendasar. Walaupun terdapat perbedaan antara wanita dan laki-laki tetapi perempuan haruslah memiliki kesempatan yang sama dengan laki-laki seperti kesempatan memperoleh pendidikan, aktualisasi diri, dan berkiprah di dalam masyarakat.

\section{b. Analisis Konsumsi Teks}

Khalayak sasaran UMMI ialah kaum perempuan beragama Islam, berusia antara 26 sampai 35 tahun dengan status sosial kalangan menengah, menekuni dunia dakwah, kalangan ibu-ibu yang baru menikah maupun belum menikah.

\section{c. Analisis Praktek Sosiokultural}

1) Peran Ganda Perempuan

Dalam artikel Dunia Mau Kiamat, Menjadi Leader dengan Wirausaha dan Istri Masalah, seorang perempuan (istri) digambarkan harus tetap menjalankan peran mereka dalam sektor rumah tangga walaupun mereka telah ikut berperan serta dalam mencari nafkah. Seorang suami harus tetap bertugas dalam mencari nafkah untuk keluarganya.

Ketiga artikel ini ditulis ketika banyak kaum perempuan yang ikut serta berpartisipasi dalam sektor publik. Robert M. Jackson mensinyalir adanya kemajuan dalam bidang ekonomi dan transformasi politik telah menurunkan tingkat 
ketimpangan gender dimana perempuan sudah banyak yang berkiprah di sektor publik. Selain itu juga faktor atas kebutuhan finansial dan kebutuhan akan aktualisasi diri juga menjadi penyebab masuknya perempuan ke sektor publik (Coltrain and Adams, dalam Skolnick and Skolnick, ed, 2001: 103).

Munculnya hasil dari Konferensi Perempuan Internasional I yang dilakukan di Kota Mexico yang memutuskan untuk menyatakan periode 1975-1985 sebagai Dasawarsa PBB untuk pembangunan merupakan salah satu faktor yang ikut mendorong perempuan untuk lebih dapat berperan di sektor publik. ${ }^{16}$

Pada masa Orde Baru, perempuan dipaksa kembali untuk tetap memegang teguh peran domestiknya. Peran ganda wanita tersebut dapat dilihat dalam Garisgaris Besar Haluan Negara (GBHN 1978, 1983 dan 1987). Pemerintah dengan tegas mengakui pembedaan peran secara seksual antara laki-laki dan perempuan dan menyatakan bahwa peran serta kaum perempuan dalam proses pembangunan harus berkembang selaras dan serasi dengan peran mereka dalam meningkatkan kesejahteraan keluarga dan generasi muda. Dengan kata lain peran yang diberikan kepada perempuan ialah peran ganda dalam arti perempuan harus bertanggungjawab atas urusan rumah tangga tetapi juga diharapkan melakukan aktivitas di luar rumah. $^{17}$

Anjuran diperbolehkannya perempuan bekerja di luar rumah tangga ini melahirkan konsep peran ganda perempuan, yakni perempuan boleh bekerja di sektor publik, tetapi dengan syarat hal ini tidak mengganggu peran domestiknya. Hal ini dicerminkan pertama oleh peranannya sebagai ibu rumah tangga, yang melakukan pekerjaan rumah tangga (memasak, mengasuh anak dan sebagainya), suatu pekerjaan produktif yang tidak langsung menghasilkan pendapatan karena pekerjaan tersebut memungkinkan anggota keluarga lainnya mendapatkan penghasilan secara langsung.

2) Kesetaraan Wanita dengan Pria dalam Islam

Dalam artikel Fitnah Dunia Kerja, Sholihat di Dalam dan di Luar Rumah, mendorong perempuan untuk mengaktualisasikan ilmu yang mereka miliki dan perempuan digambarkan mempunyai pilihan untuk berkarya di luar rumah (sektor publik) atau tetap tinggal dalam rumah tangga.

Kedua artikel ini dilatarbelakangi oleh timbulnya tuntutan persamaan hak dan peran antara perempuan dan laki-laki di kancah publik pada saat sekarang ini. Menurut Moeslim Abdur Rahman ada beberapa faktor yang mempengaruhinya. Pertama, faktor dan pengaruh dari gerakan feminisme di Barat. Di era serba global saat ini, informasi semakin mudah didapat, termasuk kiprah perempuan di Barat dengan cepat dapat ditangkap di belahan timur. Kedua, kenyataan bahwa banyaknya kaum perempuan di dunia Arab dan Islam lainnya yang ingin menuntut pendidikan lebih tinggi. Ketiga, adanya globalisasi sehingga kaum perempuan mengalami demonstration effect dari proses globalisasi. ${ }^{18}$

Kedudukan perempuan dalam pandangan ajaran Islam memandang sama antara perempuan dan laki-laki. Dalam Islam pula, posisi perempuan yang bekerja, sebagaimana yang ditegaskan oleh Engineer bahwa dalam ekonomi industri modern perempuan harus memainkan peranan yang semakin besar. Tidak ada ajaran dalam AlQur'an yang menghalangi perempuan bekerja dan memperluas kiprah publiknya. Pandangan bahwa seorang perempuan yang ideal adalah yang hanya menjaga rumah dan mengasuh anak-anaknya adalah pandangan yang tidak Qur'ani. Hal yang dituntut 
Al-Qur'an bukanlah agar dia tidak dapat bekerja tetapi bahwa laki-laki harus menafkahi isterinya sebagai balasan kepada isteri yang telah memelihara anak.

Hal ini berarti, tidak melepaskan seorang perempuan dari haknya untuk bekerja tetapi membangun kesejajaran antara isteri dan suami, antara perempuan dan laki-laki. Karena itu, tidak ada halangan bagi perempuan untuk keluar rumah dan ikut mencari nafkah, asalkan ia tetap menjaga kesuciannya dan menahan diri dari dorongan seksualnya (wayahfazhna Furujahunna), hal yang sama juga dituntut dari laki-laki (wayahfazhufurujahum). ${ }^{19}$

Satu contoh kesetaraan peran publik perempuan yang diajukan Engineer dalam bukunya, The Rights of Women in Islam adalah tentang wacana perempuan menjadi kepala negara. Diakuinya, secara mutlak memang tidak ada pernyataan langsung AlQur'an tentang kiprah publik semacam ini. Tetapi, sebaliknya, juga tidak ada ayat AlQur'an yang secara tegas menyatakan penolakan terhadap kekuasaan Ratu Saba yang memerintah kawasan Yaman sekarang sebagai wilayah kekuasaannya. Bahkan dalam Al-Qur'an, Ratu Saba digambarkan sebagai Ratu yang independen dan terlepas dari pengaruh pejabat-pejabat lelaki dalam mengambil kebijakan politiknya.

Selain itu juga dapat dilihat dari aktifitas perempuan sahabat rasullullah dalam panggung bisnis, politik, pendidikan, keagamaan dan sosial, dan ikut serta dalam peperangan dengan sektor yang mereka mampu melakukan. Sirah kehidupan istri-istri Rasul pun mengindikasikan aktifitas aktif dimana ummul mukminin Khadijah ra. adalah salah satu kampiun bisnis pada masa itu, Aisyah ra. adalah perawi hadis dan banyak memberikan fatwa karena kecerdasannya. Bahkan hawa feminispun telah terdengar dari suara-suara protes dan pertanyaan yang diajukan Ummu Salamah ra. atas eksistensi perempuan. $^{20}$

Berdasarkan hasil analisis dengan metode critical discourse analysis (CDA) diperoleh data bahwa majalah UMMI ikut mengajak dan memperkukuh norma-norma atau nilai yang ada dalam masyarakat. Majalah UMMI sebagai suatu media dakwah berusaha untuk mengajak kepada pembacanya untuk melakukan peran ganda dalam keluarga.

Representasi peran ganda tersebut dipengaruhi oleh faktor individual pembuat teks, melalui latar belakang gender, etnis dan orientasi religius yang dimiliki oleh para crew media UMMI. Selain itu, faktor rutinitas kerja UMMI turut mempengaruhi sosialisasi peran gender tersebut. Dari faktor rutinitas ini terlihat pemilihan terhadap narasumber dari suatu berita. Wartawan dalam tahap pencarian beritanya, sejak awal sudah harus menentukan pilihan narasumber yang patut dihubungi, pertanyaan atau persoalan yang mesti diajukan sementara pada proses penulisan berita, wartawan juga harus memilih fakta yang mana yang harus didahulukan dan fakta mana yang harus diceritakan.

Shoemaker dan Reese mengatakan bahwa sikap, nilai serta keyakinan pribadi komunikator juga mengarahkan latar belakang dan pengalaman profesional komunikator. Pengalaman profesional ini berdampak langsung pada isi media massa. Dari level discourse practice diperoleh data bahwa para pekerja media UMMI bekerja sesuai dengan nilai-nilai serta keyakinan yang dipegang. Mereka menginternalisasikan nilai-nilai keislaman dalam kehidupan sehari-hari termasuk dengan menjalani peran ganda. Untuk dapat menjalani peran tersebut, para pekerja media UMMI pun berusaha mengatur jam kerja dan membuat aturan-aturan yang tidak bertentangan dengan peran mereka di sektor publik. Kebijakan perusahaan dimana UMMI bernaung juga mendukung peran mereka dimana mereka memberikan kebebasan bagi para awak media UMMI dalam bekerja. 


\section{Kesimpulan}

1. Majalah UMMI secara konsisten mengkonstruksikan peran ganda perempuan dan mendukung adanya pembagian peran di dalam keluarga. Ini disebabkan adanya ideologi yang dipegang oleh UMMI sebagai suatu organisasi yang memiliki tujuan dakwah. Oleh karena itu, setiap pengetahuan yang disampaikan UMMI kepada para pembacanya haruslah sesuai dengan visi dan misi yang diemban UMMI untuk menjadikan pembaca UMMI menjadi perempuan yang baik.

2. Dikaitkan dengan teori yang berasal dari Shoemaker dan Reese, faktor para pekerja media UMMI serta ideologi yang dipegang UMMI turut bermain dalam memproduksi suatu teks.

3. Dari level teks, peneliti memperoieh 5 frame atau bingkai yang dibawa oleh UMMI, yaitu peran ganda, menjaga niat dalam bekerja, dikotomi peran dalam keluarga, mandiri, dan kesetaraan. Dari level teks ini tercermin ideologi yang dipegang UMMI yaitu Islam.

4. Dari level discourse practice terkuak bahwa UMMI merupakan suatu media yang sejak awal pendiriannya telah memposisikan dirinya sebagai media dakwah. Sebagai sebuah media Islam, UMMI berusaha untuk menampilkan dan memberikan informasi sesuai dengan visi serta misi yang diemban UMMI.

5. Dari aspek praktek sosial budaya (sosio cultural practice) terlihat bahwa timbulnya teks tersebut ternyata dipengaruhi oleh beragam faktor yang berasal dari luar, diantaranya ialah banyaknya kaum perempuan yang berkiprah di sektor publik disebabkan oleh adanya kemajuan di bidang ekonomi, transformasi politik, kebutuhan akan finansial dan aktualisasi diri.

\section{ENDNOTE}

${ }^{1}$ Indraswan, 2004, Dikotomi Gender dari http: //www.yahoo.com

2 Ratna Megawangi, Membiarkan berbeda: Sudut Pandang baru tentang relasi Gender, (Bandung: Mizan, 1999), hlm. 19.

3 Idi Subandi Ibrahim dan Hanif Suranto, Wanita dan Media: Konstruksi Ideologi Gender dalam Ruang Publik Orde Baru, (Bandung: Remaja Rosda Karya, 1998), hlm. 94.

4 Ibid., hlm. 334-344.

${ }^{5}$ Pamela J Shoemaker dan Stephen D Reese, Mediating The Message, (longman, 1996), hlm. 4.

${ }^{6}$ Ibid., hlm. 144.

7 Stephen W Littlejohn, Theories of Human Communication, $7^{\text {th }}$ edition, (Belmont California: Wadsworth Publishing Company, 2002), hlm. 309.

8 Shoemaker dan Reese, op.cit., hlm. 231.

${ }^{9}$ Mansour Fakih, Analisis Gender dan transformasi Sosial, (Yogyakarta: Pustaka pelajar,2003), hlm. 7-8.

${ }^{10}$ Mansour fakih, Membincang Feminisme: Diskursus Gender Perspektif Islam, (Surabaya: Risalah Gusti, 1996), hlm. 461.

${ }^{11}$ Eriyanto, Analisis Wacana: Pengantar Analisis Teks Media, (Yogyakarta: LKIS, 2001), hlm. 4-7.

${ }^{12}$ Ibid., hlm. 285.

${ }^{13}$ Norman Fairclough, Media Discourse, (London: Edward Arnold, 1995), hlm. 55-56.

14 Alex Shobur, Analisis Teks Media: Suatu penngantar untuk Analisis Wacana, Analisis Semiotik dan Analisis Framing, (Bandung: PT Remaja Rosda karya, 2001), hlm. 162.

15 Ibid., hlm. 177.

16 Ratna Saptari dan Brigitte Holzner, Perempuan, Kerja dan Perubahan Sosial, (Jakarta: Pustaka Utama Grafiti, 1997), hlm. 154.

${ }^{17}$ Bainar, Wacana Perempuan dalam Keindonesiaan dan kemodernan, (Jakarta: Pustaka Cisendo, 1998), hlm. 241-242.

${ }^{18}$ Moeslim Abdurrahman, Perlu mereformasi “Fikih Perempuan”, Republika, 12 September 2003, hlm. 7.

${ }^{19}$ Syarief Hidayatullah dan Mukhtassar, etika Al-Qur'an Bagi Peran Publik Publik,.( http://www.yahoo.com) 
${ }^{20}$ Kuni Khaerunnisa, Perspektif Jender dalam islam: Islam backing Feminisme?, http: //www.pesantren virtual.com, 11 Juni 2001

\section{DAFTAR PUSTAKA}

Bainar, (editor). 1998. Wacana Perempuan dalam Keindonesiaan dan Kemodernan. Jakarta: Pustaka Cisendo.

Eriyanto. 2003. Analisis Wacana: Pengantar Analisis Teks Media. Yogyakarta: LKIS.

Fakih, Mansour. 2003. Analisis Gender dan Transformasi Sosial. Yogyakarta: Pustaka Pelajar.

. 1996. Membincang Feminisme: Diskursus Gender Perspektif Islam Surabaya: Risalah Gusti.

Fairclough, Norman. 1995. Media Discourse. London: Edrward Arnold.

Ibrahim, Idi Subandi \& Suranto, Hanif. 1998. Wanita dan Media, Konstruksi Ideologi Gender dalam Ruang Publik Orde Baru. Cet. I, Bandung: Remaja Rosda Karya.

Littlejohn, Stephen W. 2002. Theories of Human Communication, $7^{\text {th }}$ Edition. Belmont, California: Wardsworth Publishing Company.

Megawangi, Ratna. 1999. Membiarkan Berbeda: Sudut Pandang Baru tentang RElasi Gender. Bandung: Mizan.

Salim, Agus. 2001. Teori dan Paradigma Penelitian SOsial: Dari Denzin dan Penerapannya. Yogyakarta: Tiara Wacana.

Saptari, Ratna dan Holzner, Brigitte. 1997. Perempuan, Kerja dan Perubahan Sosial. Jakarta: Pustaka Utama Grafiti.

Shoemaker, Pamela J dan Reese, Stephen D. 1996. Mediating The Message. Longman

Sobur, Alex. 2001. Analisis Teks Media: Suatu Pengantar untuk Analisis Wacana, Analisis Semiotik dan Analisis Framing. Bandung: PT. Remaja Rosda Karya.

\section{Surat Kabar}

Abdurrahman, Moeslim. Perlu Mereformasi Fikih Perempuan. Republika 12 September 2003.

\section{Majalah}

Dunia Mau Kiamat, UMMI edisi 7/X/98

Fitnah Dunia Kerja, UMMI, edisi 11/X/99

Bekerja on Mission, UMMI, edisi 11/X/99

Istri Masalah, UMMI, edisi 8/XII/2000

Shalihah di dalam Dan di luar Rumah, UMMI, edisi 6/XIV/2002

\section{Website}

Indraswan, 2004, Dikotomi Gender, http://www.yahoo.com.

Hidayatullah, Syarief dan Mukhtassar. M, Etika Al-Qur'an Bagi Peran Publik Perempuan. http://www. Yahoo.com.

Khairunnisa, Kuni. Perspektif Jender dalam Islam: islam Backing Feminisme?,11 Juni 2002, http://www.pesantren virtual.com. 